\title{
Health needs and forms of meeting these needs during the SARS-CoV-2 coronavirus pandemic in Poland, with particular consideration of the domain of psychological health
}

\author{
Potrzeby zdrowotne i formy ich zaspokajania w czasach pandemii \\ koronawirusa SARS-CoV-2 w Polsce, ze szczególnym uwzględnieniem \\ obszaru zdrowia psychicznego
}

\author{
Adela Teleon ${ }^{1, A-D \oplus}$, Anna Włoszczak-Szubzda ${ }^{2, B, D-F \odot ~}$ \\ ${ }^{1}$ Institute of Rural Health, Lublin, Poland \\ 2 University of Economics and Innovation, Lublin, Poland \\ A - Research concept and design, B - Collection and/or assembly of data, C - Data analysis and interpretation, \\ $D$ - Writing the article, E-Critical revision of the article, $F$ - Final approval of article
}

Teleon A, Włoszczak-Szubzda A. Health needs and forms of meeting these needs during the SARS-CoV-2 coronavirus pandemic in Poland, with particular consideration of the domain of psychological health. Med Og Nauk Zdr. 2020; 26(3): 191-195. doi: 10.26444/monz/126263

\begin{abstract}
Introduction. Considering the confirmed data concerning the spread of SARS-CoV-2 coronavirus which causes Covid-19 disease, on 11 March 2020, the Director of the World Health Organization (WHO) announced a pandemic in 114 countries, with the exception of China. In Poland, the first case of SARS-CoV-2 coronavirus infection in a patient was confirmed on 4 March 2020; actions were therefore undertaken to limit the transmission of the virus among the population, and an attempt made to adjust the existing model of health services to the new conditions of an epidemiological threat.
\end{abstract}

Objective. The aim of the study is presentation of health needs brought into focus in Poland as a consequence of SARS-CoV-2 coronavirus pandemic, especially in the care of psychological health, and actions undertaken to enable medical staff to care for patients during the pandemic.

Results. In the situation of the pandemic in Poland, solutions were introduced aimed at better provision of services, including many teleconsultations. At the same time, the pandemic brought into focus a greater demand than before for the care of patients in the domain of psychological health. There occurred states of fear and anxiety concerning the risk of SARS-CoV-2 coronavirus infection and an uncertain future. Social isolation also enhanced domestic violence. Barriers have become clear in the teleworking of medical staff.

Conclusions. The pandemic forced a change in our every-day reality, our usual rituals, adopted directions of action, and plans for today and tomorrow. However, there are also some advantages resulting from the current situation, which forces the use of new media in medical practice and contributes to their more frequent use. In consequence, this will reduce

Address for correspondence: Anna Włoszczak-Szubzda, University of Economics and Innovation, Projektowa 4, 20-209, Lublin, Poland

E-mail: a-wlos@tlen.pl

Received: 05.05.2020; accepted: 10.08.2020; first published: 03.09.2020 technophobia in medical circles and increase the availability of medical specialists for patients.

\section{Key words}

SARS-CoV-2 coronavirus, health needs, psychological health, physicians, nurses, telemedicine

\section{Streszczenie}

Wprowadzenie. Z uwagi na potwierdzone dane dotyczące rozprzestrzeniania się koronawirusa SARS-CoV-2, który wywołuje chorobę Covid-19 w Chinach oraz 114 innych krajach, dyrektor Światowej Organizacji Zdrowia WHO 11 marca 2020 roku ogłosił pandemię. W Polsce zachorowanie pierwszego pacjenta na wirus SARS-CoV-2 potwierdzono 4 marca 2020 roku, w związku z czym podjęto działania ograniczające transmisję wirusa wśród ludności oraz próbę dostosowania istniejącego modelu świadczeń zdrowotnych do nowych warunków zagrożenia epidemicznego. Cel pracy. Celem pracy jest przedstawienie potrzeb zdrowotnych uwidocznionych w Polsce w następstwie pandemii koronawirusa SARS-CoV-2, szczególnie w opiece z zakresu zdrowia psychicznego, oraz podjętych działań umożliwiających opiekę personelu medycznego nad pacjentami w czasach pandemii. Wyniki. W sytuacji pandemii w Polsce wprowadzono rozwiązania mające na celu lepsze zabezpieczenie świadczeń, w tym także liczne teleporady. Jednocześnie pandemia ujawniła większe niż dotychczas potrzeby opieki zobszaru zdrowia psychicznego nad pacjentami. Ujawniły się stany niepokoju i lęku dotyczące niebezpieczeństwa zakażenia koronawirusem SARS-CoV-2 czy niepewnej przyszłości. Izolacja społeczna nasiliła także przemoc domową. Uwidoczniły się bariery w telepracy medyków. Wnioski. Pandemia spowodowała zmianę naszej codzienności, naszych zwykłych rytuałów, przyjętych kierunków działań, planów na dziś i jutro. Są jednak pewne korzyści z aktualnej sytuacji. Wymusza ona używanie nowych mediów w praktyce medycznej i przyczynia się do częstszego korzystania z nich, 
a co za tym idzie przypuszcza się, że zmniejszy w środowisku medycznym technofobię i zwiększy dostęp pacjentów do specjalistów medycznych w podstawowym zakresie.

\section{Słowa kluczowe}

zdrowie psychiczne, pielęgniarki, lekarze, telemedycyna, potrzeby zdrowotne, koronawirus SARS-CoV-2

\section{INTRODUCTION}

Considering the confirmed data about the spread of SARS-CoV-2 coronavirus (Severe Acute Respiratory Syndrome Coronavirus 2), causing Covid-19 disease (Coronavirus Disease), on 11 March 2020, the Director of the World Health Organization (WHO) announced a pandemic in 114 countries, with the exception of China [1]. In Poland, the first case of a patient infected with SARS-CoV-2 was confirmed on 4 March 2020. The spread of the virus is by droplet transmission, as well as contact with surfaces contaminated with the virus; actions were therefore implemented in order to limit its spread among the population [2]. The closures of schools, galleries, points of services, the necessity for remote work from home instead of places of work, mobility restrictions, staying at home, and the possibility to go outside only in justifies cases, resulted in a state of isolation of society which generated additional health needs, as well as a change in the way of provision of services to-date. Based on the data by the Ministry of Health, this was accompanied by a constant increase in the number of cases of infection with the virus: on 25 March in Poland, there were 1,051 cases of infection and 14 persons deceased; on 30 March this number increased to 2,055 infected persons and 31 deceased; on 7 April there were as many as 4,848 infected and 129 deceased; on 15April - 7,582 infected and 286 deceased; on 22 April - 10,034 infected and 404 deceased, and on 27 April the number of infected persons had risen to 11,902 and 562 deceased [3]. This situation brought into focus deficits in health care and forced the necessity for undertaking actions which would result in supporting medical staff and the introduction of new possibilities for providing health services. In addition, this situation made it clear that the system of health care in the domain of psychological health is more vulnerable than in other areas of health care.

Limited knowledge concerning COVID-19 and overwhelmingly depressing news in the media led to fear and anxiety in society $[4,5]$, further exacerbated by the general enforced isolation [6]. Apart from physical suffering, it often happened that psychiatric patients with confirmed of suspected COVID-19 suffer from high psychological pressure and other health problems. Confirmed and suspected cases of COVID-19 among psychiatric patients may cause the feeling of fear of the serious consequences of the disease and infection [7]. In consequence, the patients may also experience loneliness, depression, and despair, which may additionally contribute to the lack of observance of the therapeutic recommendations. In some psychiatric patients there may occur an increased risk of aggression and even suicide. The fear experienced of uncertainty concerning their state of health may develop into obsessive-compulsive symptoms, such as frequently repeated measurement of temperature or excessive antisepsis. In addition, strict lockdown and obligatory tracing of contacts by health services may cause the feeling of social rejection, financial loss, discrimination and stigmatization $[4,5,6]$. The latest international scientific reports identify four areas of vulnerability of patients with mental disorders during this pandemic:
1) concomitant diseases, which occur more frequently in patients with mental disorders (cardiovascular and pulmonary, diabetes, obesity, etc.), and are risk factors of severe Covid-19 infection, therefore causing additional fears and anxiety;

2) age of psychiatric patients (depressions at old age), the elderly are the most exposed to coronavirus in the population;

3) cognitive and behavioural disorders, which may hinder perception of restrictive and hygienic measures;

4) psychosocial sensitivity as a result of stigmatization and/ or socio-economic difficulties. Scientific reports also prognosticate the epidemic of emotional disorders caused by all factors of the pandemic. They postulate additional medical staff trained in the area of prevention, detection, and treatment of early warning signs of post-traumatic stress disorder which will become apparent in the general population, in psychiatric patients, and especially among medical staff $[8,9]$.

\section{OBJECTIVE}

The aim of the study is presentation of the health needs brought into focus in Poland as a consequence of SARS-CoV-2 coronavirus pandemic, especially in the care of psychological health, and actions undertaken to enable medical staff to care for patients during the pandemic.

\section{STATE OF KNOWLEDGE}

Shortages of physicians and nursing staff. According to the report by the Economic Cooperation and Development (OECD) for the EU countries concerning the number of physicians, in 2010 in Poland, there were 2.2 physicians per 1,000 inhabitants; in 2016-2.4 physicians per 1,000 inhabitants, and the same number in 2019. The mean number of physicians for OECD countries in 2019 was 3.5; therefore the situation in Poland looked very unfavourable; moreover, only 8 out of the 44 countries analyzed had a lower rate of physicians per 1,000 population, compared to Poland. It should also be noted that the data from the report differ from those published by the Supreme Medical Council, because they show that in 2016 there were 133,000 physicians, which indicated 3.5 physician per 1,000 inhabitants; however, this group of physicians also included those who paid premiums, but stayed abroad, i.e. physicians who do not constitute staff resources in Poland. In turn, in accordance with the Central List of Insured, to which all citizens belong who are occupationally active and pay premiums, there were 117,000 physicians, which indicates greater staff resources than that indicated in the OECD report $[10,11]$.

In addition, apart from the shortages of medical staff, the OECD report indicated that during the period 2014-2018, in Poland the number of nurses per 1,000 inhabitants was 5.1, which means the Poland occupied the third place from 
the end among the countries of the European Union [11]. These data are also confirmed by the report «Professions Barometer 2020> within an all-Polish study conducted by the Regional Labour Office in Białystok by order by the Minister of Labour and Social Policy in 2020, which demonstrates that physicians and nurses should be classified into understaffed occupations [12].

Considering the necessity for increasing the number of physicians based on possible actions resulting from the Act introduced on 2 March 2020 in the matter of special solutions associated with prevention, counteracting and control of COVID-19, other infectious diseases and crisis situations caused by these situations (Journal of Laws 2020, Clause 374), regulation by the Minister of Health of 16 March 2020, amending the regulation in the matter of guaranteed services in the area of nursing and care within long-term care (Journal of Laws 2020, Clause 460), and also the regulation by the Minister of Health of 16 March 2020, amending the regulation in the matter of guaranteed services in the area of palliative and hospice care (Journal of Laws 2020, Clause 457), the regulation by the Minister of Health of 17 March 2020 , amending the regulation in the matter of guaranteed services in the area of hospital treatment (Journal of Laws 2020, Clause 466), and the regulation by the Minister of Health of 16 March 2020, amending the regulation in the matter of guaranteed services in the area of psychiatric care and addictions treatment (Journal of Laws 2020, Clause 456), the number of physicians was increased by periodical admission of physicians who, because of the SARS-CoV-2 coronavirus pandemic, could not take the State specialization examination to provide services. In addition, it was proposed to repeal the employment standards for nurses and midwives with respect to the bed occupancy rate, and to restore the state in which the provision of patient care would take place based on the regulation by the Minister of Health of 22 November 2013 in the matter of guaranteed hospital treatment services (Journal of Laws of 2017, Clause 2295, with later amendments). The requirements concerning the ascribed bed occupancy rate were very difficult to implement by services provides during the time before the pandemic, and have become even more difficult in the pandemic situation $[13,14,15,16,17]$. The proposed solutions resulted from the occurrence of an increased demand for medical and nursing staff. International data indicate the demands in this are: a Chinese study which included 1,563 medical staff showed that more than a half (50.7\%) of them working in the pandemic reported depressive symptoms, $44.7 \%$ - symptoms of anxiety, and $36.1 \%$ - sleep disorders. They often reported excessive loading with work, isolation, and discrimination. In the struggle with Covid-19, medical staff are especially susceptible to the experience of physical exhaustion, fear, and emotional disorders. To the duty of care for the infected patients there is the added fear for loved ones, of risk in contacting family and or relatives, and sometimes even facing public investigation, blame or hatred $[5,7,18]$.

Deficit of advice using tele-information systems. According to Article 15 of the Act of 27 August 2004 in the matter of medical services financed from public resources (Journal of Laws 2019, Clause 1373, with amendments) patients may use guaranteed services in individual areas of services, such as: primary health care, outpatient health care, hospital treatment, dental treatment, therapeutic rehabilitation, psychiatric care and addictions treatment, palliative and hospice care, emergency medical services, nursing and care services within long-term care, spa treatment, health programmes, and highly specialist services; in addition, they may use medications, foods for particular nutritional uses, as well as medical products [19]. The regulations by the Minister of Health in the matter of guaranteed services in individual areas specify the conditions in which the services are provided. Before the pandemic, the services were provided under outpatient and inpatient conditions, in conditions of daily care, environmental and home care, directly in the contact patient/medical staff, and it was possible only in primary health care to give medical advice using remote tele-information systems or communication systems [20].

In order to prevent the spread of the coronovirus, and simultaneously make it possible to provide health services, a number of consultations and visits were introduced using the tele-information systems or communication systems. It has become possible to provide services in the form of advice, visits and consultations in nursing and care services in long-term care, in palliative and hospice care, outpatient specialist care, in psychiatric care and addictions treatment, or therapeutic rehabilitation. Moreover, in accordance with the announcement by the National Health Fund concerning the provision and cost accounting of hospital services - drug programmes and hospital treatment with chemotherapy, in association with prevention, counteracting and control of COVID-19, it was made possible to dispense medicines to patients for use at home for the period of 6-month therapy, and also to provide medical advice, not only in person, but also in the form of telephone consultation. In a similar way, it is possible to provide follow-up consultations for patients whose state is stable $[21,22]$.

Tele-medical consultations may take place via tele-information systems: on the phone, chat or video conversation. The physician takes the patient's medical history, and at the end of such a tele-consultation may issue an e-prescription, e-referral, e-sick leave, or suggest a direct visit to a medical centre, or contact a sanitary-epidemiological station if necessary. A 'tele-visit' lasts for 10-50 minutes, depending on the medical problem [23]. Also, the platforms for telemedicine provide the patient with the possibility to review their referrals, history of visits, sick leaves and prescriptions. Tele-medicine is therefore not only a way for providing epidemiological safety. From the economic aspect, due to tele-medicine, physicians maintain the continuity of work, and the outpatient department gains resources during this time, which is uncertain not only from the point of view of health, but also financially. Directly after completion of a consultation, the physician automatically sends information to the National Insurance Fund, and settles the cost of tele-consultation without using any other system [24].

The greatest barrier in this work may be the security of sensitive personal information, and the difficulties incurred are the weakness in Internet links. It is not always possible to provide tele-advice, e.g. it is not possible to remotely perform pre-natal examinations, or provide assistance in a situation of the aggravation of a disease, e.g. a cardiovascular disease. A psychological barrier for telemedicine services is the perception of such a form of contact as dehumanizing by both parties of the physician-patient relatioship, which hinders the establishment of interpersonal relationship leading to trust indispensable in the process of nursing and treatment. 
The shortage of consultations in the area of psychiatry is especially visible. The pandemic has brought into the focus considerably greater needs in the care of patients with psychiatric disorders. In society, states of anxiety about an uncertain future in connection with the pandemic are more frequently revealed; additionally, the pandemic exerts an especially negative effect on patients because it imposes a change in life style, such as observance of disinfection and sterility recommendations, or social isolation. There also occur the feeling of fear associated with the risk of becoming infected with the SARS-CoV-2 coronavirus. In emotionally unstable persons there may occur an intensification of disorders, especially as a result of omnipresent information concerning the results of the pandemic [25]. Taking into account the scale of the needs, by the regulation of the Minister of Health of 16 March 2020, amending the regulation in the matter of guaranteed services in the area of psyciatric care and addictions treatment (Journal of Laws 2020, Clause 456), it was made possible to provide a number of outpatient services using the tele-information systems, including outpatient psychiatric services for adults, children and adolescents, as well as the treatment of neurosis, sexological and pathology of intercourse services, psychological services, services for patients with childhood autism, or other overall development disorders, provided in the form of medical consultations, psychological advice or sessions. In addition, it was made possible to provide tele-advice designed for patients using addiction therapy [17].

Considering the many signals from services providers and from experts in the domain of psychiatry, as well as from patients, concerning the constantly unsatisfied need for psychological assistance, the National Health Fund launched 24-hour psychological support within telephone patient information. Additionally, patients can use several-minute films from the series «Psychological support during pandemic) which facilitate the solving of problems such as: fear of isolation, conflicts in the family, depressed mood, or fear related with loss of employment.

The National Health Fund also began cooperation with the Ministry of National Defence in the area of the creation of an additional possibility for patients, especially those in quarantine, to use the assistance of psychologists from the Territorial Defence Forces. Assistance is also provided by psychologists from the Polish Insurance Company Health who are experienced in remote work with patients. Duties are provided within a telephone helpline for patient information and are available around the clock daily to help persons in emotional crisis, who badly tolerate seclusion and experience stress and fear caused by the epidemiological situation [26]. Additionally, within the action, psychologists and psychotherapeutists provided free support for society by means of generally available forms of communication (phone, SMS, e-mail, skype, whatsapp, messenger), in various languages, including English, Spanish, Ukrainian, and German [27]. In addition, it operates around the clock the Centre of Support for persons in psychological crisis at the ITAKA Foundation «Memory Phone for seniors, established on the initiative of the National Museum at Majdanek in Lublin, and a number of self-government initiatives undertaken in individual provinces within psychological support for citizens, e.g. the Psychological Centre of Support functioning in Warsaw for parents and schoolchildren in difficult situations associated with the pandemic, or support programme by the Medical
University in Wrocław for medical; staff and employees of pharmacies carried out by psychologists, psychiatrists and psychotherapeutists [28, 29, 30, 31].

Assistance with care in the coordination of mental health during the pandemic is generally indispensable for all, irrespective of age and profession; however, information provided on the websites of the Ombudsman concerning the growing wave of domestic violence, occur to be especially regrettable. Unfortunately, the consequences of isolation and quarantine are also very frequently alarm signals informing about harm, suffering, and humiliation, i.e. violence experienced by close persons within the enclosed four walls of a home. In association with the need for the support of persons threatened by domestic violence, as a result of cooperation with the Ombudsman's Office, the 'Feminoteka' Foundation, the Centre for Women's Rights and the 'Blue Line' of the Institute of Psychology of Health, a document 'Emergency Plan for persons experiencing domestic violence in coronavirus epidemic' was produced, which contains information about the possibilities of receiving help during an epidemic or pandemic by all who experience violence within their own homes. It is also worth mentioning the initiative 'Telephone for spiritual support', initiated by Archbishop Grzegorz Ryś, where spiritual fathers are on duty and provide assistance in a difficult time for everyone [32, 33].

Similar to other medical specialities, the new instrument for work with a patient also creates certain barriers. To these instrument belongs the issue of patient identity, especially during the first visit. There is still a lack of reliable procedures in the area of tele-medicine, which may be overused, e.g. by patients needing prescriptions. Other barriers include, among others, problems with breaking the connection, with establishing video contact, especially contact recommended in the area of psychological health for establishing professional bonds, as well as maintaining patient intimacy in contact with a physician; in these cases, conversations via a microphone and speakers are preferred which allow privacy [34, 35].

\section{CONCLUSIONS}

The state of a pandemic shows the importance of care and health assistance in the area of human health, especially in the domain of psychological health at a time of social isolation. It seems that the pandemic has not exerted such an effect on any of the areas of provision of service, nor has it triggered more growing needs than those in psychiatry. Evaluation of the effects of shortages in meeting the demands will be possible only after completing the struggle with the invisible opponent which can ruin mental healthy and even result in death.

It is likely that the idea of psychologists from the Jagiellonian University in Kraków and the project the 'Letter to quarantine' addressed to all people for whom the state of pandemic is a very difficult experience, would allow a summary of the psychological state of society. The project, by using a computer or hard copy, enables the description of own thoughts, which may contribute to coping with negative feelings, as well as by mailing a letter to the University or its e-mail box, which would allow experts to read the contents and provide answers to the problems presented.

The pandemic has changed our everyday life, our rituals, routine directions of action, plans for today and tomorrow. 
However, there are some benefits from the current situation. It compels the use of new media in medial practice, and contributes to their more frequent use, consequently decreasing technophobia in medical circles, and increasing patients' accessibility to medical specialists. The current situation also indicates the need for the creation of psycho-somatic teams in health care to satisfy patients' needs and, simultaneously, the need for personal care and occupational support for nursing and medical staff.

\section{REFERENCES}

1.WHO. Coronavirus disease 2019 (COVID-19) Situation Report - 51 https://www.who.int/docs/default-source/coronaviruse/situation-reports/20200311-sitrep-51-covid-19.pdf?sfvrsn=1ba62e57_10 (dostęp: 2020.04.28)

2. Nitsch-Osuch A. Koronawirus raz na dziesięć lat. Medycyna dydaktyka wychowanie. MDWUM Warszawski Uniwersytet Medyczny. Warszawa 2020; 2: 10-13.

3. Mapa zarażeń koronowirusem (SARS-Co-2). Ministerstwo Zdrowia. Warszawa 2020. https://www.gov.pl/web/koronawirus (dostęp: 2020.04.15).

4. Shigemura J, Ursano RJ, Morganstein JC, Kurosawa M, Benedek DM. Public responses to the novel 2019 coronavirus (2019-nCoV) in Japan: mental health consequences and target populations. Psych Clin Neurosci. 2020.

5. Bao Y, Sun Y, Meng S, Shi J, Lu L. 2019-nCoV epidemic: address mental health care to empower society. Lancet (London, England). 2020.

6. Brooks SK, Webster RK, Smith LE, Woodland L, Wessely S, Greenberg $\mathrm{N}$, The psychological impact of quarantine and how to reduce it: rapid review of the evidence. Lancet (London, England). 2020.

7. Xiang Y-T, Yang Y, Li W, Zhang L, Zhang Q, Cheung T, Timely mental health care for the 2019 novel coronavirus outbreak is urgently needed. Lancet Psychiatry. 2020.

8. Chevance A, Gourion D, Hoertel N, Llorca P-M, Thomas P, Bocher R, Moro M-R, Laprévote V, Benyamina A, Fossati P, Masson M, Leaune E, Leboyer M, Gaillard R. Ensuring mental health care during the SARS-CoV-2 epidemic in France: a narrative review. Encephale. 2020 Apr 22, doi: 10.1016/j.encep.2020.04.005.

9. Starace F, Ferrara M. COVID-19 disease emergency operational instructions for Mental Health Departments issued by the Italian Society of Epidemiological Psychiatry. Epidemiol Psychiatr Sci. $2020 \mathrm{Mar}$ 31;29:e116. doi: 10.1017/S2045796020000372.

10. Liczba lekarzy w Polsce rośnie, problemem jest starzenie się kadr. Czwarta konferencja w ramach debaty „wspólnie dla zdrowia” wypowiedź w trakcie wykładu „kadry w zasobach NFZ” Narodowy Fundusz Zdrowia. Lublin 2019. https://www.rynekzdrowia.pl (dostęp: 2020.04.15).

11. OECD Health Statistics 2019. https://www.oecd-ilibrary.org (dostęp: 2020.04.15).

12. Barometr zawodów 2020. Wojewódzki Urząd Pracy w Białymstoku. Kraków 2019. https://barometrzawodow.pl (dostęp: 2020.04.16).

13. Ustawa z dnia 2 marca 2020 r. o szczególnych rozwiązaniach związanych z zapobieganiem, przeciwdziałaniem i zwalczaniem COVID-19, innych chorób zakaźnych oraz wywołanych nimi sytuacji kryzysowych (Dz. U. 2020 poz. 374).

14. Rozporządzenie Ministra Zdrowia z dnia 16 marca 2020 r. zmieniające rozporządzenie w sprawie świadczeń gwarantowanych z zakresu świadczeń pielęgnacyjnych i opiekuńczych w ramach opieki długoterminowej (Dz. U. z 2020 poz. 460).

15. Rozporządzenie Ministra Zdrowia z dnia 16 marca 2020 r. zmieniające rozporządzenie w sprawie świadczeń gwarantowanych z zakresu opieki paliatywnej i hospicyjnej (Dz. U. z 2020 poz. 457).

16. Rozporządzenie Ministra Zdrowia z dnia 17 marca 2020 r. zmieniające rozporządzenie w sprawie świadczeń gwarantowanych z zakresu leczenia szpitalnego (Dz. U. z 2020 poz. 466).

17. Rozporządzenie Ministra Zdrowia z dnia 16 marca 2020 r. zmieniające rozporządzenie w sprawie świadczeń gwarantowanych z zakresu opieki psychiatrycznej i leczenia uzależnień (Dz. U. z 2020 poz. 456).

18. Wen Li, Yuan Yang, Zi-Han Liu, Yan-Jie Zhao, Qinge Zhang, Ling Zhang, Teris Cheung, Yu-Tao Xiang. Progression of Mental Health Services during the COVID-19 Outbreak in China. Int J Biol Sci. 2020; 16(10): 1732-1738.

19. Ustawa z dnia 27 sierpnia 2004 r. o świadczeniach opieki zdrowotnej finansowanych ze środków publicznych (Dz.U. z 2019 poz. 1373 ze zm).

20. Rozporządzenie Ministra Zdrowia z dnia 24 września 2013 r. w sprawie świadczeń gwarantowanych z zakresu podstawowej opieki zdrowotnej (Dz. U. z 2019 poz. 736 ze zm.).

21. Komunikat dotyczący realizacji i rozliczania świadczeń w rodzaju Leczenie szpitalne - programy lekowe oraz leczenie szpitalne - chemioterapia w związku z zapobieganiem, przeciwdziałaniem i zwalczaniem COVID-19. Narodowy Fundusz Zdrowia. nfz.gov.pl/aktualności/ aktualności-centrali/programy-lekowe-a-covid (dostęp 2020.04.19).

22. Rozporządzenie Rady Ministrów z dnia 31 marca 2020r (Dz.U. z 2020 poz. 566).

23. Pustułka A. Przychodnie w czasie pandemii: wszystko o teleporadach, wywiad z P.Spyra https://dziennikzachodni.pl/przychodnie-w-czasie-pandemii-wszystko-o-teleporadach-dr-piotr-spyra-z-centrum-medycznego-graniczna-o-telewizytach-u-lekarzy/ar/c14-14879135 (dostęp: 2020.04.20).

24. Świrydowicz K. Czas telemedycyny. Jak uzyskać poradę lekarską podczas epidemii koronawirusa. Wywiad z P. Ogórek https://zdrowie. wprost.pl/koronawirus/w-polsce/10311125/czas-telemedycyny-jak-uzyskac-porade-lekarska-podczas-epidemii-koronawirusa.html (dostęp: 2020.04.22).

25. Heitzman J. Wpływ pandemii COVID-19 na zdrowie psychiczne. Polskie Towarzystwo Psychiatryczne. Psych Pol. 2020:54(2) 3-4

26. Narodowy Fundusz Zdrowia. nfz.gov.pl/aktualności/aktualności/-centrali/zalodobowe-wsparcie-psychologiczne (dostęp: 2020.04.23).

27. Psychologowie i psychoterapeuci dla społeczeństwa. https://www. psychologowie-dla-spoleczenstwa.pl/kontakt (dostęp: 2020.04.23).

28. Centrum wsparcia dla osób w stanie kryzysu psychicznego. www. liniawspracia.pl (dostęp: 2020.04.24).

29. Telefon pamięci, czyli wsparcie dla seniorów w pandemii. Polskieradio24.pl (dostęp: 2020.04.24).

30. Koronawirus-wsparcie psychologiczne i dydaktyczne dla rodzin. um.warszawa.pl (dostęp: 2020.04.24).

31. Bezpłatna pomoc psychologiczna dla wrocławian, lekarzy, pielęgniarek i farmaceutów. www.wroclaw.pl (dostęp: 2020.04.25).

32. Plan awaryjny- jak szukać pomocy, gdy doświadczamy przemocy domowej w trakcie epidemii. rpo.gov.pl (dostęp: 2020.04.25).

33. Kapłan pod telefonem - Duchowe wsparcie. archidiecezja.lodz.pl (dostęp:2020.04.26).

34. Kurzyńska E. Teleporada psychiatryczna w czasie pandemii koronawirusa. https://pulsmedycyny.pl/teleporada-psychiatryczna-w-czasie-pandemii-koronawirusa-98876 (dostęp: 2020.04.27).

35. Listy do kwarantanny. https://psychologia.uj.edu.pl/kwarantanna/ listy-do-kwarantanny (dostęp: 2020.04.27). 